Xavier ROMERO-FRIAS

independent scholar

xavierromerofrias@gmail.com

\title{
RULES FOR MALDIVIAN TRADING SHIPS TRAVELLING ABROAD (1925) AND A SOJOURN IN SOUTHERN CEYLON
}

ABSTRACT 'Rules for Maldivian Trading Ships', the translated document that forms the first part of the paper is a twelve-page manual published by the Royal House on the rules that were to be followed by Maldivian oceangoing ships while on their yearly trading trip to "the continent" (kara). Kara referred primarily to the island of Ceylon (Sri Lanka), the foreign place that Maldivian traders found most convenient to reach. This trade originated in most major islands of the archipelago in the past, including Minicoy (Maliku), but was vital for the communities living in the atolls located at the southern end of the chain. The second part of the paper includes the translation of a personal account by an old Maldivian trader about his experiences in and around Gali (Galle, Sri Lanka), the description of conditions in the harbour and an inland town in Ceylon, as well as the friendships he established there with local people.

Keywords: Indian Ocean, trade, Maldives, Sunni Islam, Intercultural dialogue 
$\mathrm{T}$ he Maldives is an archipelago of coralline atolls located in the middle of the ancient seafaring route that stretched across the northern expanses of the Indian Ocean. The Kingdom of the Maldive Islands was well-known among early mariners for the good quality of its coir rope and the abundance of cowry shells, the latter being a very important trade item in Asia and parts of Africa until the $19^{\text {th }}$ century. Some of the earliest reports about this long inhabited island group were written by Chinese and Arab navigators over a thousand years ago, ${ }^{1}$ but the first detailed account was made by Moroccan explorer Ibn Battuta when he visited the Maldives in the $14^{\text {th }}$ century. ${ }^{2}$

Although lagoons in the scattered atolls provide fairly safe anchorage, the Maldives lacked visible natural landmarks, as well as good harbours serving cities with significant populations. Most ships sailing east or west between the Arabian Peninsula and Southeast Asia naturally attempted to avoid the thousands of hidden dangers of the flat and lengthy stretch of shallow waters. Navigators sought to cross the area through one of the broad channels between the atolls, but many a fully-laden ship ended up wrecked in one of the treacherous reefs of the Maldives, for which the islands earned a rather unsavoury reputation as a perilous place in the ancient route.

Despite this unavoidable notoriety, there are records in history about large vessels covering the trade route that stopped over - more or less intentionally - in one of the islands of the Maldives. During their stopover such ships typically purchased cowries, tortoise-shell, ambergris and coir rope. But these were events that took place only occasionally and it cannot be affirmed that any place in the Maldives was anything close to a commercial emporium. What is far more likely is that the products valued by foreign traders were brought by Maldivians themselves in significant quantities to the superior trading harbours of Ceylon, South India and Bengal ensuring a constant supply that would be available for the larger seafaring craft plying the route in an east or westward direction. Indeed, the trade conducted by Maldivians between their atolls and those nearby harbours was part of a seasonal commercial tradition that has never been suitably documented although it is mentioned in time-honoured Maldivian poetry. ${ }^{3}$

In much the same manner as the shores of the Indian Subcontinent, the Maldives has been inhabited for a very long time. The nation developed a civilization of its own that - according to the evidence provided by copious archaeological remains - had flourished by the early Postclassical Era. Since their culture was based on navigation and trade, constant commercial trips to the coast of the neighbouring countries were nothing less than vital for Maldivians. ${ }^{4}$

C. Maloney, People of the Maldive Islands, New Delhi 1980, ed. 2013, pp. 416-420.

2 Ibn Battuta, Travels in Asia and Africa, trans. by H.A.R. Gibb, London 1929, pp. 365-370.

3 See 'Introduction: Maldivian Folklore and Popular Literature in the Divehi Language' in X. Romero-Frias, Folk Tales of the Maldives, Copenhagen 2012.

4 Idem, The Maldive Islanders. A Study of the Popular Culture of an Ancient Ocean Kingdom, Barcelona 1999, pp. 49-51. 
Documents about Maldivian trading ships travelling abroad are exceptional in the annals of the Atoll Kingdom. The book of rules, translated by the author of this paper, was meant to be used by Maldivians merely for practical purposes; however, it contains noteworthy facts about the nature of the trade and the protectionist policies of the state.

From one side the salient features of the regulations are concerned with health safety measures in order to keep the isolated and relatively vulnerable communities in the islands free from contagion. These are embodied by the quarantine procedures and the advice to Maldivians staying at foreign harbours. The other components of the rules betray an anxiety about the possible introduction of weapons and materials that could be used in an insurgency, as well as an attempt to keep political dissidents at bay by advising travelling traders to ostracize exiled Maldivians that may have been involved in political conspiracies.

The seasonal trade between the larger inhabited islands of the Maldives and the nearest coasts was essentially a form of peaceful coexistence that never hit the headlines of history. Every year, Maldivians in their far-flung atolls filled their vessels with island products - mainly dry tuna and coconut-based sweets in the last phase of the historic trade - and the fully-loaded ships sailed to Ceylon or South India, only to return a few months later with valuable cargo. This outbound trade was facilitated by a regular pattern of seasonal winds blowing in a south-westerly and then shifting to a north-easterly direction. ${ }^{5}$

The oceangoing merchant ships which were the object of the Maldivian treasury rules were heavy craft, designed to be filled up to the brim with cargo. H. Warington Smyth, of the Royal Thames Yacht Club, described them thus in 1906:

The most remarkable vessel, however, is the large Maldive trader, running to a hundred tons or more in size. She is fully decked, with considerable deckhouses and big overhanging forecastle. The rig is a three-mast arrangement: a tall mainmast carries a big main squaresail set high up with topsail and occasional small topgallant sail. The mizzen carries a fore-and-aft gaffsail. Forward is a raking foremast carrying a square foresail well out over the bows. One may meet these vessels occasionally as far north as the Hugli, and with fair monsoon they are rapid passage-makers, but beating to windward is not their forte. ${ }^{6}$

Although this customary trading endeavour is manifestly very ancient, it was not mentioned in Maldivian epigraphy. ${ }^{7}$ As a consequence, there is no written evidence regarding the yearly travel to the closest shores until 1735, when a Maldivian trading boat that had drifted into the Southern Atlantic Ocean was rescued by a British ship. The boat was found thousands of miles to the west of its original destination, past the Cape of Good Hope. Only five men, a woman and a boy survived; they were brought to St. Helena and were never sent back to the Maldives.

B. Koechlin, 'Notes sur l'histoire et le navire long-courrier, odi, aujourd'hui disparu, des Maldives', Archipel, Vol. 18, No. 1 (1979), pp. 283-300.

6 H.W. Smyth, Mast and Sail in Europe and Asia, London 1906.

H.C.P. Bell, who wrote at length about the Maldives in the early $20^{\text {th }}$ century in his monograph The Máldive Islands. Monograph on the History, Archaeology and Epigraphy, s.l. 1940, did not write about this topic. 


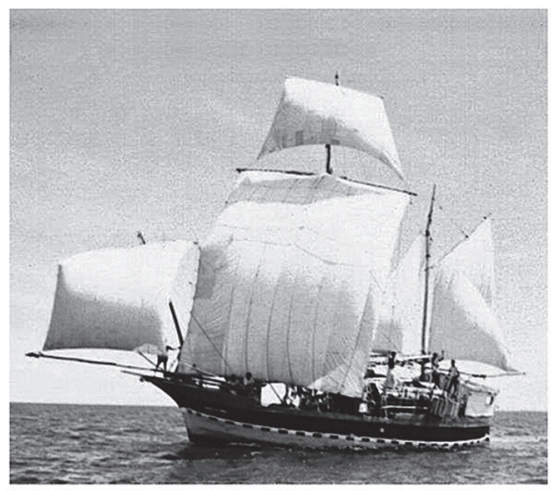

On the right a map of the Maldive Islands, including the nearest landmasses to the Northeast, and above a Maldivian trading ship from the southern atolls.

Although Southern India is technically closer to the Maldives, trade with the main western harbours of Ceylon (Colombo and Galle) was favoured by Maldivian merchants for their yearly trading journey.

\section{Picture : Mohamed Didi (Modi).} Map by James Horsburgh (1762 - 1836), hydrographer of the East India Company.

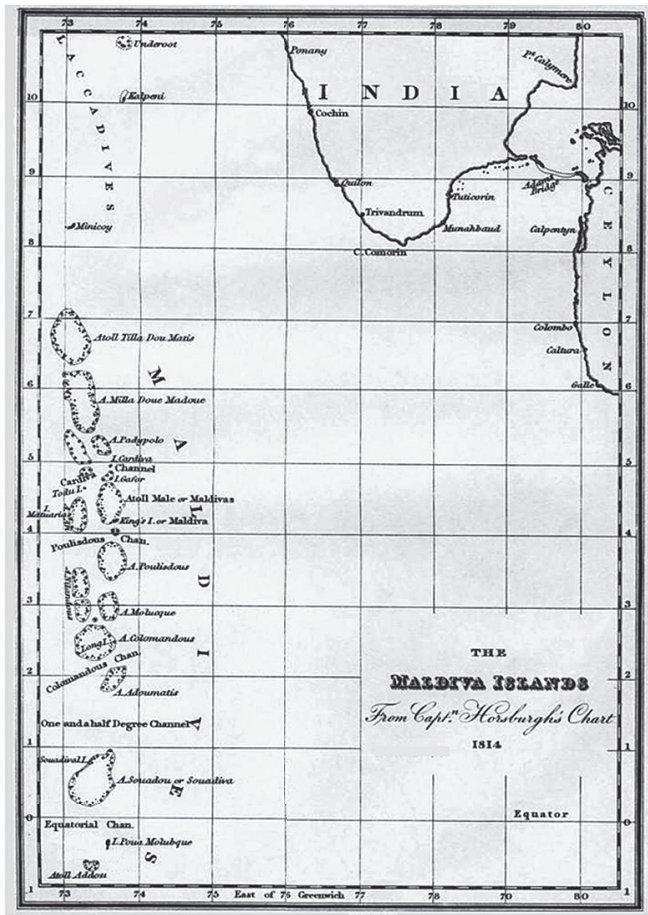

...Captn Pelly at the distance of 150 Leagues from Land took up a Boat with Ten Blacks in her belonging to of the Maldive Islands called who were drove out to sea \& near perishing having no more Provisions or Water left when he see them than about Ten pounds of Rice \& Three Gallons of Water three of the Ten died on board the other Seven Vizt. 5 men one boy \& one Woman he hath left here \& wee shall keep them at Work for their Living till wee hear from Honours how they Shall be sent back to their own Country... ${ }^{8}$

The risk of getting lost and dying at sea, or to never be able to return home, was always high, but the ocean trade was indispensable for the southern atolls. The Maldivian monarchy in Male, wary of the freedom of interaction of its citizens with people of foreign countries, would have preferred to establish a policy of isolationism but for centuries the oceanic trade escaped state control.

The option to post customs agents in the Southern Atolls to collect the taxes was not available to the government. The atolls at the southern end of the archipelago were too remote and there was no way of taxing the trade that did not pass through the capital. Moreover, there were no effective means of ensuring the long-term allegiance towards Male' of the person that would be responsible for collecting the taxes and forwarding the funds to the capital. Even a northern official posted in the distant south

8 'Letters to England 1727-1737' in J. Tyrell, Return to Maldivia: Happy Ending or Anti-Climax?, 12 April 2013, at <http://johntyrrell.blogspot.com/2013/04/return-to-maldivia-happy-ending-or-anti.html>. 
would 'go native' after a few years, seeing his loyalties divided. Thus, for a very long time the treasurers of the Island Kingdom had to tolerate the two way trade. ${ }^{9}$

By issuing the rules and enforcing them the Maldivian monarchy chose a radical form of centralization, in which the only door through which all trade entered the country would be Male' harbour. This measure favoured control from the capital, but it would end up negatively affecting the economy of the southern atolls in the $800-\mathrm{km}$-long atoll chain. The traditional travel to Ceylon and back, with the added risk of getting lost in the vast Indian Ocean, became a lengthier three-leg trip.

The second part describes the contacts made by a trader while ashore in Ceylon. The events, narrated by Vaijehēge Ali Didi, a jeweller from Fua Mulaku who had made several trips to Ceylon, took place in and around Galle Harbour - located at the southern end of the large island - around the mid 1960s.

Ali Didi's attitude towards the local Muslims of Southern Ceylon, though admitting discrepancy in religious matters, is non-judgmental. He points out matter-of-factly the differences he noticed in the way other Muslims lived their faith. But he in no way questions their dignity and refrains from emphasizing his own personal orthodoxy in some religious practices. Neither has he attempted to censor his friends nor the people he met during his trip for not living up to his standards; he merely records their admiration at the fact that "he prayed a lot" and that he could read Arabic well. By and large, Ali Didi considers the traders from Ceylon first and foremost his friends and, while reminiscing and telling the story, he spoke about them with a gentle smile on his face.

What is notable about Ali Didi's account is the embodiment of the traditional longanimity of Muslim societies in South and Southeast Asia in the past. ${ }^{10}$ Customary respect towards those members of the community who were devout in religious matters went hand in hand with the respect and affection towards those who chose not to follow the religion strictly. The current general intransigence in religious matters and the resulting intolerance are a relatively recent phenomenon in the region. ${ }^{11}$ In the past, there were many ways of living Islam in daily life and not everyone was required or expected to display religious fervour. Although elderly pious people were held in obvious reverence, lack of consideration towards non-religious people was for the most part absent in traditional South Asian Islamic communities.

Finally, towards the end of the narrative Ali Didi engages in the performance of a magic ritual followed by the making of simple protective amulets for his hosts. The reputation of Maldivians as skilled in the magic arts was prominently mentioned by Portuguese travellers in centuries past. Duarte Barbosa wrote about the inhabitants of the 'Ilhas do Maldio' that ...they had no weapons and were slender people, but very ingenious and, most of all, great magicians. ${ }^{12}$ Current legalistic religious movements frown

9 M. O'Shea, The Revolt of the Southern Atolls of Maldives 1959-63, 1998, ed. 2009, at <http://hamdhoonrasheed.blogspot.com/2011/10/revolt-of-southern-atolls-of-maldives.html>.

10 For a description of the ancient Islamic virtue of 'Hilm' see L. Gardet, Les hommes de l'Islam. Approche des mentalités, Paris 1977, p. 34 (Le Temps \& Les Hommes).

11 X. Romero-Frias, The Maldive Islanders..., p. 650.

12 as gentes dellas não tem armas, e são homens fracos, mas muito engenhosos, e sobre tudo grandes encantadores. Livro de Duarte Barbosa (1518), p. 352. 
upon magic practices. Al Didi, however, did not see any contradiction between the practice of sorcery and his everyday Islamic piety.

\section{PART I. RULES FOR MALDIVIAN TRADING SHIPS}

Translation and analysis of the 'Rules for Maldivian Trading Ships' issued by the Maldivian Royal Government in 1925 on the subject of the official attempt at regulation of the yearly seasonal trade between certain islands of the Maldives and the nearest coasts. Comments and explanations are in italics.

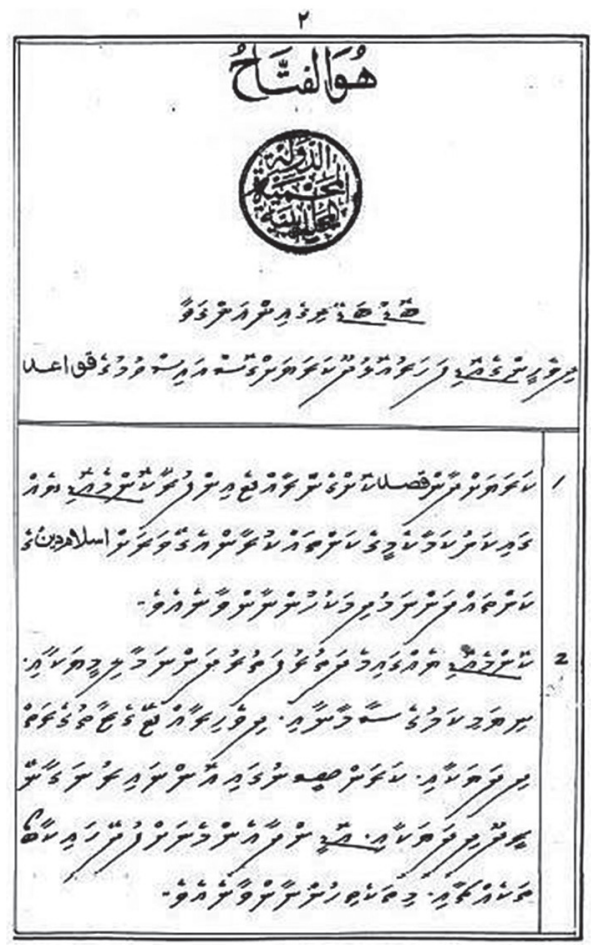

(Page 2. The document begins here, the first page being the blank cover)

Heading: He who decides (In Arabic: Huwal Fatah, from one of the names of God, Al-Fattah "The Decider")

Seal: State Tribunal of Maldives (In Arabic: Ad Daulat Al Mabkamiyat Al Mahaldibiyat)

Issued by: The Royal Treasurer's Authority (Boḍu Badẹeri)
Title: Rules for Maldivian Trading Ships travelling from and to Ceylon (Oluudūkara)

Rule One: In every Trading vessel (odii) leaving the Maldives and bound for the continent (kara) there should be a mudimu (religious leader), knowing the essentials of the Islamic religion, able to ensure that (these rules) are implemented.

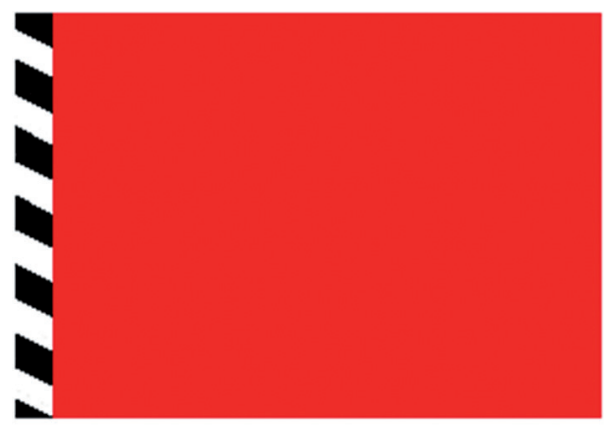

Flag of the Maldive Islands 1925

The odi trading sailships were known as vedi in the southern atolls of Fua Mulaku and Addu and as vodda in Huvadu, the largest of the southern atolls.

Rule Two: In every trading vessel there should be a navigator or pilot able to sail the ship, which should be equipped with the red Maldivian flag, as well as the yellow flag to be displayed as a signal of quarantine. The ship should also have enough water and provisions for all those travelling aboard. 


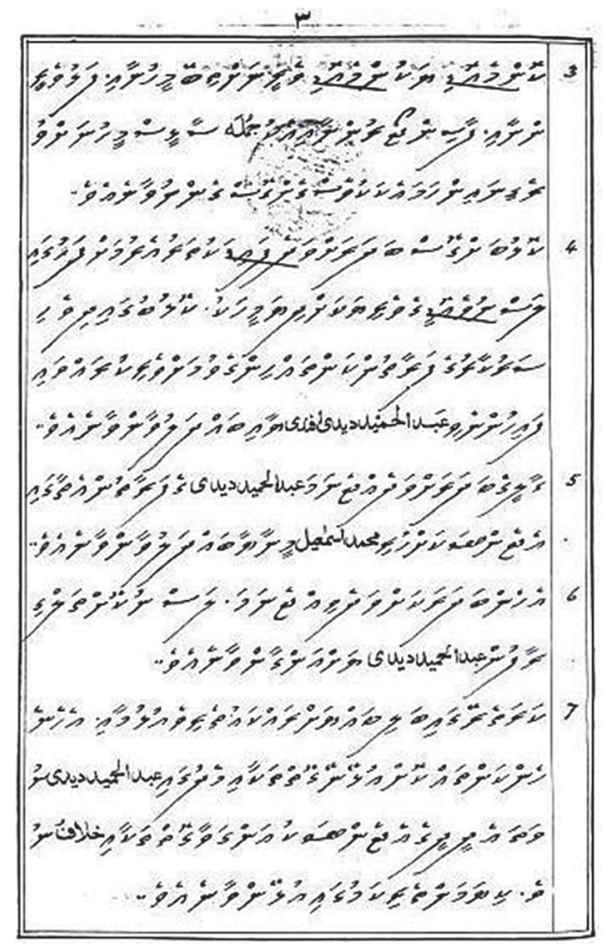

(Page 3)

Rule Three: On every trading ship there should be no more than forty people travelling, including those in command, the sailors and the passengers.

Rule Four: Upon entering Colombo (Kolubu) harbour and after the doctor (Port health authority) has come aboard, the commander of the vessel should contact the Maldivian government authority in Colombo, Abdul Hamid Didi Fandi, without delay.

Rule Five: In case of entering Galle (Gāli) harbour (the captain of the vessel) should meet Muhammad Ismaîl, the agent duly appointed by Abdul Hamid Didi.

Rule Six: In case of entering any other harbour (the captain of the vessel) should make contact with Abdul Hamid Didi by telegraph without delay.
It was not uncommon for Maldivian trading ships to arrive at less important harbours in Ceylon such as Trincomalee, where my friend and host Karange Hasan Didi had been once. Some Maldivian ships reached the South Indian coast where the preferred harbour was Cochin.

Rule Seven: In order to be protected against various diseases and other troubles while in the continent's harbours, everyone should abide by the rules set by Abdul Hamid Didi or his agent and not contravene them.

This rule is a non-explicit warning against visiting local women and risking to become infected with venereal diseases that could later easily spread in the islands.

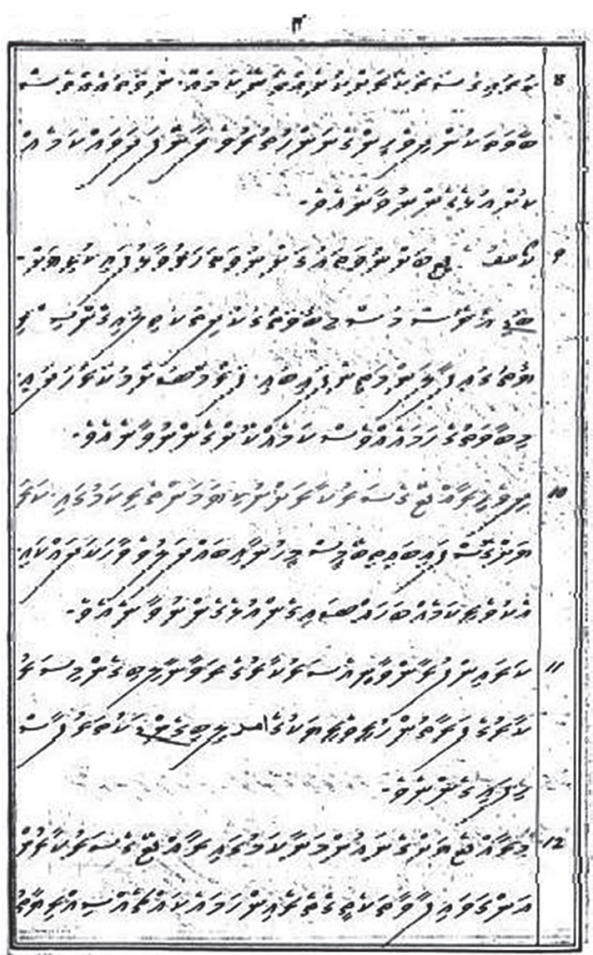

(Page 4) 
Rule Eight: (Travelling Maldivians) should not be found guilty of any fault against the government of the continent nor engage in any criminal activity that would bring a bad reputation to Maldivians.

Rule Nine: Maldivians should not abuse the terms of the permit by trying to smuggle any bodi, āros or fish hidden in their clothing when going ashore. Such actions will not be tolerated.

Bodi and àros sweets, as well as Maldive fish were the main trading items.

Rule Ten: It is strictly forbidden to contact, converse and establish a relationship with those (Maldivians) living abroad that are dissenters against the Maldivian government.

Rule Eleven: The vessel should leave the foreign harbour only after duly receiving the official dispatch of the government there and the permission of the representative of the (Maldivian) government there, as well as the medical pass.

Rule Twelve: It is strictly not allowed to bring to this Kingdom (the Maldive Islands), even in a secret way, any of the items that have been expressly forbidden by the Maldivian government.

The sentence 'even in a secret way' is used to place emphasis.

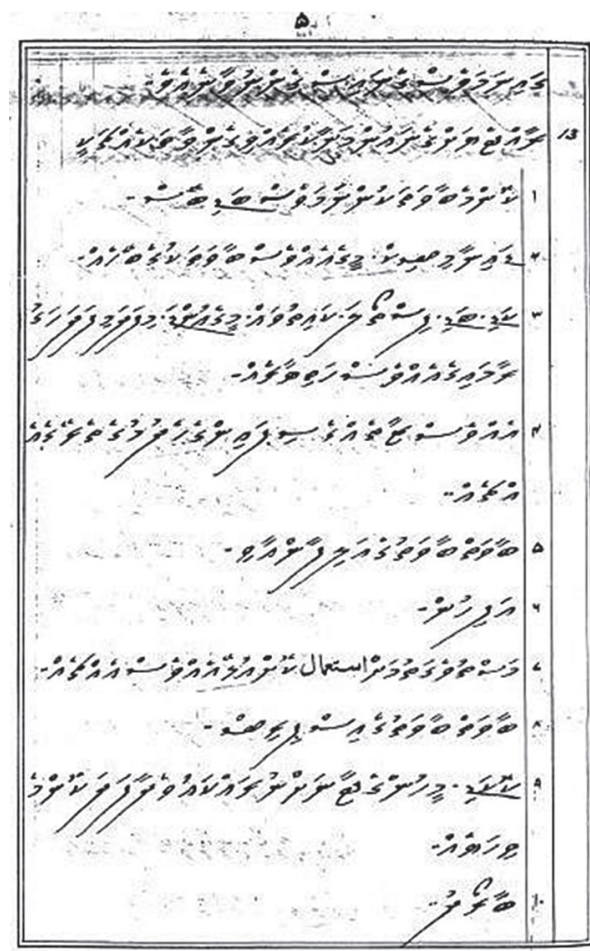

(Page 5)

Rule Thirteen: The items that are forbidden to bring to the Kingdom are:

1. Any kind of gunpowder.

2. Dynamite or any similar explosive.

3. Swords, guns, pistols and any kind of weapon used in war.

4. Any type of military uniform.

5. Any kind of corrosive acid.

6. Opium.

7. Any sort of intoxicating substance.

8. Any of the different kinds of ethyl alcohol or ethanol.

Substance abuse was rare in those times in island society. Opium was an indispensable ingredient in Divehi Bess, the Maldivian herbal or folk medicine related to Ayurveda. Opium was used mainly as a remedy against diarrhoea, but also as a pain killer in Divehi Bès. Spirits, such as brandy and ethanol, 
were also important in traditional island medicine for the preparation of medicinal syrups and alcoholic solutions of herbs.

9. Arsenic or any poison deadly to humans.

10. Saltpetre (Potassium Nitrate).

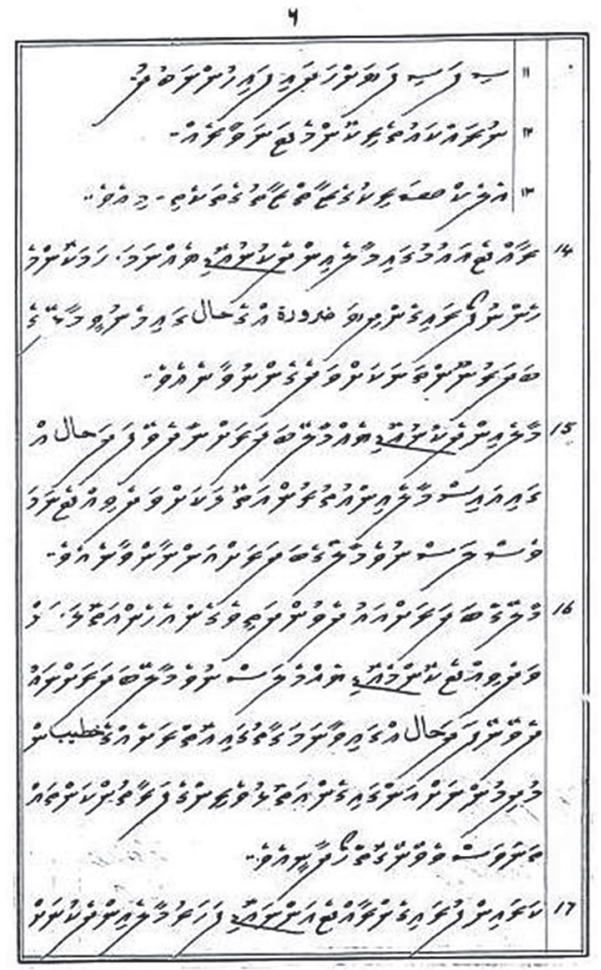

(Page 6)

\section{Any type of idol.}

An 'idol' could be any kind of figure representing a human or an animal. In the Maldivian language the same word is used for Buddha, statue, effigy and doll.

12. Any kind of dangerous animal.

13. Any electric device.

Rule Fourteen: Any trading ship from the atolls south of Male' arriving to the Maldive Islands should not enter the country at any place other than Male' harbour, except in case of severe emergency.
Rule Fifteen: Any trading ship from the Southern Atolls that finds itself in such a situation that it cannot reach Male' harbour and enters an atoll north of Male' should set sail towards Male' harbour without delay.

Rule Sixteen: Every trading ship that enters another atoll after having difficulty in reaching Male' harbour and is not in a situation to reach Male' harbour without delay, should request the Khatibu or Mudimu of the nearest island to inform the corresponding Atoll Chief in order to find a way to facilitate a solution.

Rule Seventeen: All inbound trading vessels from the continent that have entered an atoll south of Male' and have difficulty in reaching Male, should contact the Atoll Chief after having safely anchored in that atoll.

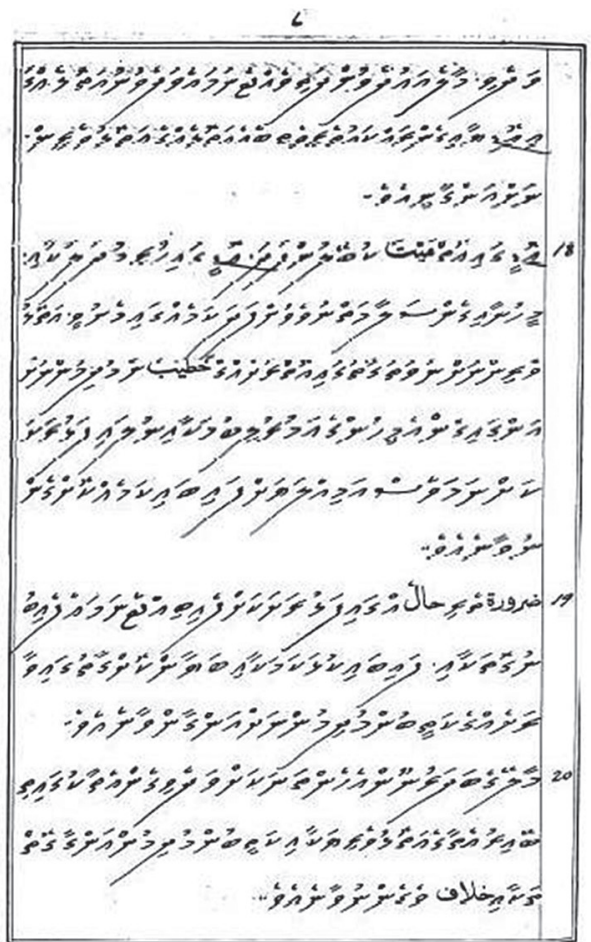

(Page 7) 
Rule Eighteen: Unless on the trading ship such a situation arises that a dead body has to be brought ashore or that the ship's cargo and travellers cannot be saved otherwise, it is strictly forbidden to go ashore at one's own discretion on any uninhabited island without duly informing the Atoll Chief or the Khatibu or Mudimu of the nearest inhabited island.

In the case of death at sea, bodies were not disposed of in the ocean. For a description of the significance of burial on land among Maldivians see the monograph 'The Maldive Islanders' by the author.

Rule Nineteen: If a landing caused by an emergency situation has taken effect on an uninhabited island, the circumstances and the reasons for disembarking will have to be reported in detail to the Khatibu or Mudimu of the nearest island.

Rule Twenty: Upon having entered another location that is not Male' harbour, it is forbidden to contradict the instructions given by the Atoll Chief or the Khatibu or Mudimu of the area.

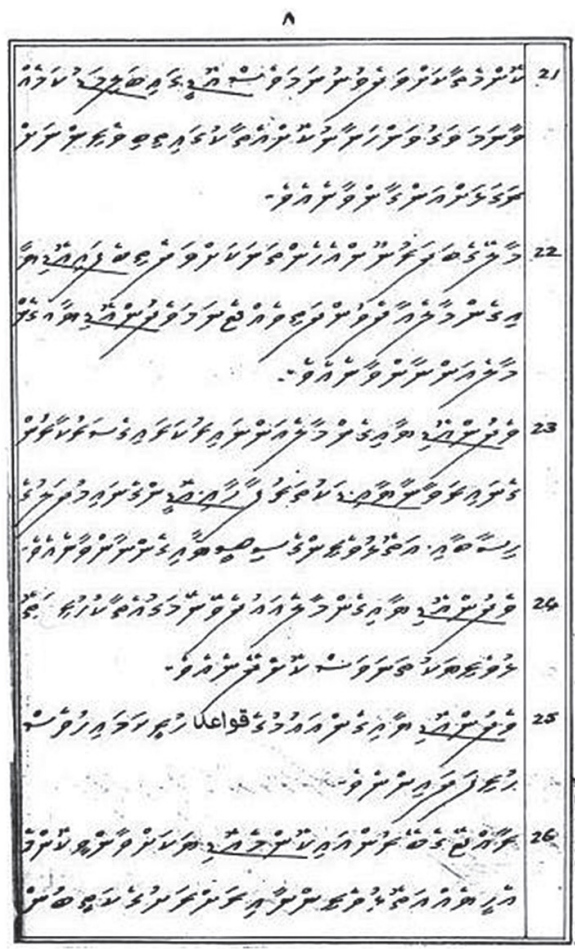

(Page 8)

Rule Twenty-one: No matter which location has been reached, if there is a situation of lack of food on the vessel, no actions amounting to stealing local produce should be taken without properly informing the authorities of that place.

Rule Twenty-two: Upon having entered any other harbour outside of Male,' owing to alleged difficulty in reaching Male' harbour, the inbound ship has to set sail towards Male' in any case.

Rule Twenty-three: Upon entering Male' harbour, every inbound ship having previously entered any other atoll, has to bring the dispatch of the Continental authorities, the medical pass, the details of the cargo as well as the letter from the Atoll Chief.

Rule Twenty-four: The inbound ship's journey to Male' will have to be 
facilitated by the corresponding Atoll Chief.

Rule Twenty-five: The (current) rules regarding inbound ships are the same as the rules that were issued previously.

Rule Twenty-six: Any ship having entered the Maldive Islands from abroad is entitled to receive every kind of assistance from the Atoll Chiefs as well as from the Khatibus or Mudimus of any atolls and islands.

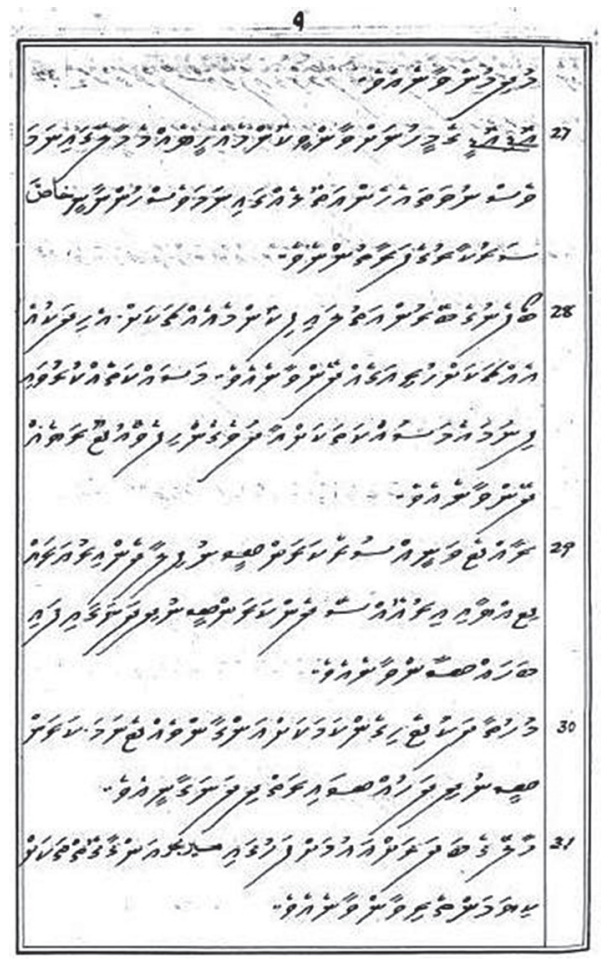

(Page 9)

Rule Twenty-seven: Any assistance to the people of the ship, whether in Male' or any atoll will be at the special expense of the government.

Rule Twenty-eight: In case of procuring drinking water from an outside party the price has to be paid in situ. Also, in case of requiring any works to be done on the ship, the customary honoraries for the work will be duly paid by the captain of the ship.

This does not include drinking water procured by other means such as water caught during squalls using the sails or tarpaulins of the ship.

Rule Twenty-nine: After arriving to the Kingdom and until the end of the quarantine period, the quarantine flag has to be flown atop the ship between sunrise and sunset.

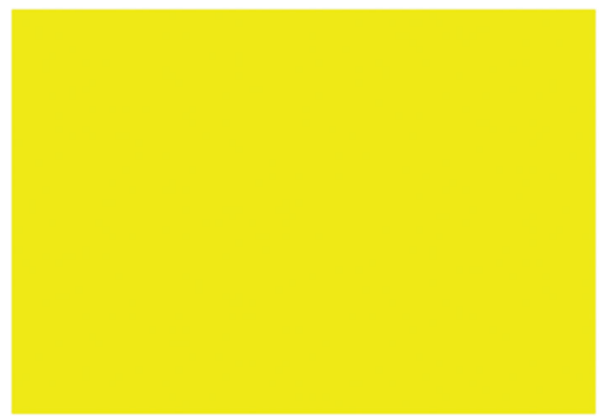

\section{Quarantine Flag 1925}

Rule Thirty: In order to announce a need, the quarantine flag will be lowered and the red flag hoisted.

Rule Thirty-one: After having entered Male' harbour the ship will have to abide by the orders of the harbour master. 


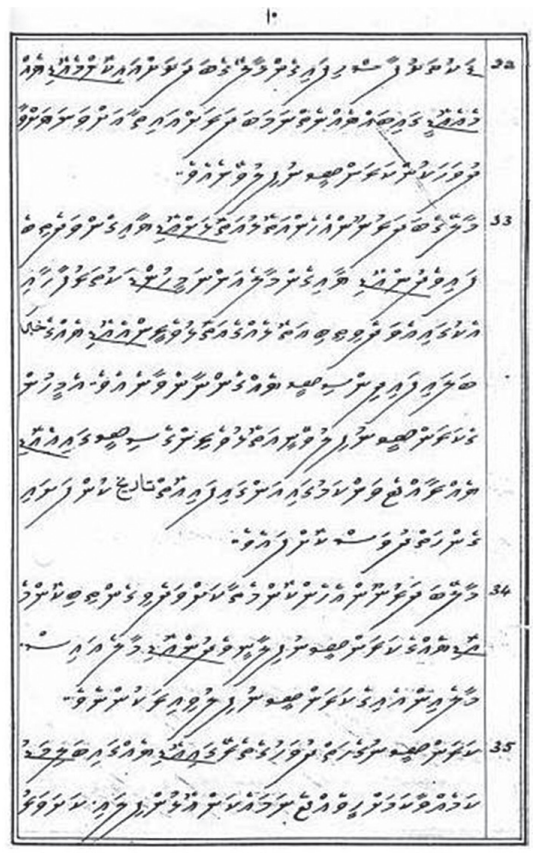

(Page 10)

Rule Thirty-two: Every ship in possession of the medical pass having arrived to Male' harbour will be cleared of quarantine after eight days, provided there is no sickness aboard.

Rule Thirty-three: Regarding the ship having arrived to another atoll before entering Male' harbour, it will have to carry the medical pass, as well as the letter of the Atoll Chief of the atoll it entered previously. Its passengers will be cleared of quarantine beginning from the date appearing on the Atoll Chief's letter, which is the date that the ship entered the Kingdom.

Rule Thirty-four: Any ship having entered another harbour other than Male' will be cleared of quarantine only after arrival to Male' and after its quarantine period has concluded.

Rule Thirty-five: The quarantine will be extended if there is a sickness on board that has been confirmed with certainty within the seven days of the quarantine period.

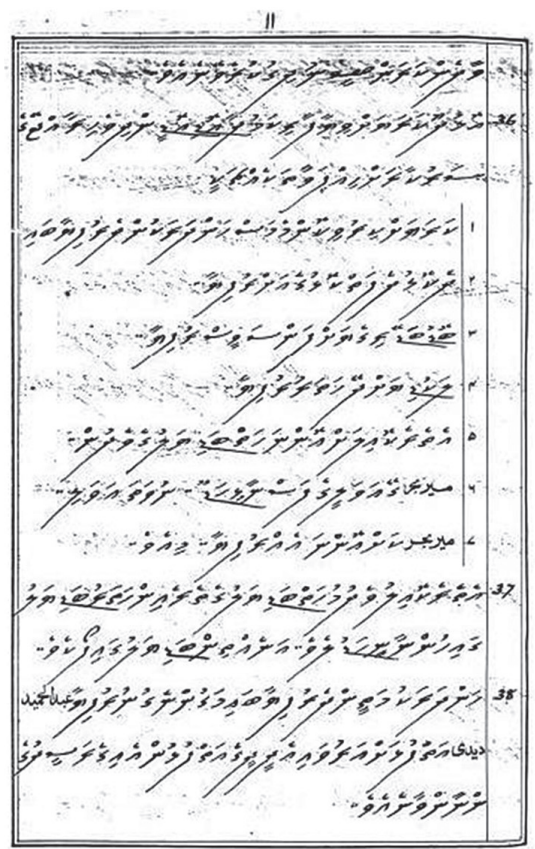

(Page 11)

Rule Thirty-six: From every trading ship having arrived from Ceylon, the following items are due to the Government of the Kingdom:

1. From every handaru that was weighed abroad 2.5 Rupees.

2. For the issue of official documents in both places 8 Rupees.

3. For the Royal treasury 25 Rupees.

4. Wood 4 Rupees.

5. For the Eterekoilu seven bandiya

6. For the harbour master's house 5 nälhi rice or crushed rice (avali).

7. For the Harbour Master 1 Rupee.

$A$ handaru is $50.8 \mathrm{~kg}$, a long hundredweight of the Imperial System. A bandiya was a squat round pot traditionally used to carry water with a capacity of about $8 \mathrm{l}$; a nälbi is $1 \mathrm{~kg}$. 
The Etherekoilu was the inner part of the palace compound, the seat of government until 1933. The armouries were also inside the Etherekoilu. The tax was for the benefit of the sultan's household, including the guards.

Rule Thirty-seven: From the bandiyā of the Eterekoilu four will be filled with rice and the other three with arecanuts.

Rule Thirty-eight: From the $2.5 \mathrm{Ru}$ pees taken for every handaru a written receipt signed by Abdul Hamid Didi should be provided.

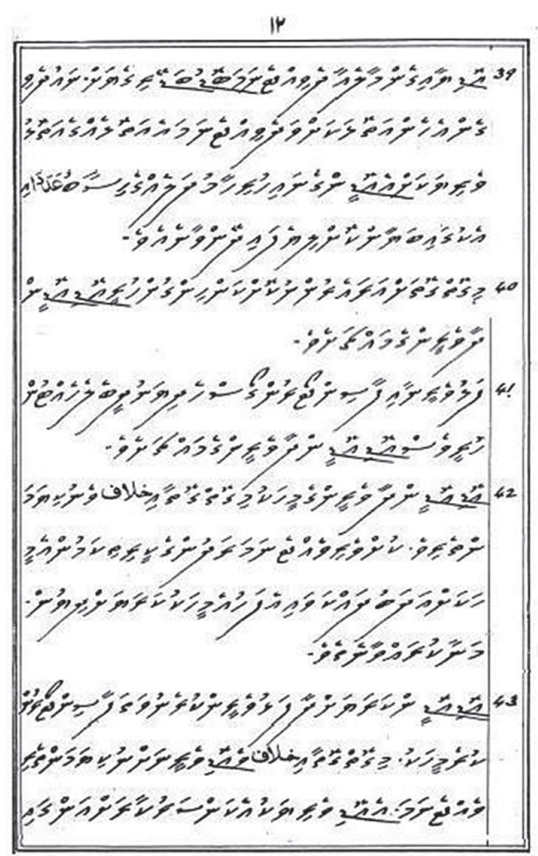

(Page 12)

Rule Thirty-nine: A Male' bound trading vessel that is unable to report to the Treasurer after anchoring in another atoll has to show the Atoll Chief of that atoll a detailed written description of its cargo.

Rule Forty: All these rules here should be implemented without argument by the captain of the ship.

Rule Forty-one: The captain of the ship is also responsible to ensure that sailors and passengers don't display improper behaviour.

Rule Forty-two: All those travelling on a trading vessel that deliberately contravene these rules will be declared guilty and given the corresponding punishment by Royal Order, being also forbidden from travelling abroad again.

Rule Forty-three: Any member of the crew or passenger of a trading vessel travelling abroad that contravenes these rules and disobeys the captain of the ship must be duly reported to the government. After the details have been provided and the corresponding punishment dispensed, it will be forbidden for that person to travel abroad in the future.

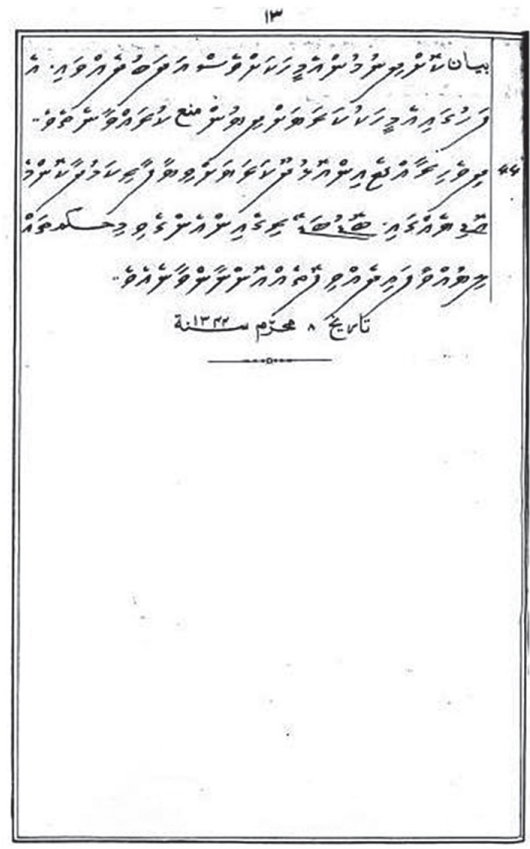

(Page 13)

Rule Forty-four: On every ship bound to Ceylon on merchant journeys there has to be a book of rules issued by the Royal Treasurer.

Date: 8 Muharram 1344 (29 July 1925) 


\section{PART II. A SOJOURN IN SOUTHERN CEYLON}

\section{By Vaijehēge Ali Didi, Fua Mulaku, Maldives}

In my trips to Gāli (Galle) I used to go very often to a certain shop. The owner was a man named Muhammadu Nūru and he had bought quite an amount of gold-ware from me. We had become friends early on and he invited me every day to share his midday meal with him in his shop. One day he told me: "You must come with me to my home." He added, "I am not from here, I am from Velipiți." I asked him when we would go. He said that he would close the shop on Saturday afternoon and all Sunday, which is their closing day.

So one Saturday evening we boarded a train together and after three hours we reached a place where we got off the train and climbed on an oxcart. Night had fallen and we progressed slowly on a narrow road through the jungle. Muhammadu told me many times: "We'll be there soon." But the road was completely dark, we crossed very few people and there was no light to be seen among the trees.

After a long time we saw some lights of petrol lamps. We had reached a cluster of houses and I could see that we were on the main street of a village. There were no electric lights in the place and I could discern a large mosque by the square. The small village soon was over and I saw more dark jungle at the other end. Suddenly we stopped and my friend jumped off the cart. Muhammadu introduced me to his uncle Abdurrazzag Nüru. He was a fat, middle-aged man. He showed me his shop and then he accompanied us to his house. After walking a while in the darkness, we arrived to a large veranda lit by petrol lamps. It was full of women and children. All were looking at me with bright eyes, smiling and chattering among each other.

Muhammadu spoke to them and introduced me: "A man from the Maldive Islands. He prays very much." Then he told the women to bring clean water. They brought the water in an enamel basin and I took it of the veranda to a well close by and made ablutions (vuzū). Muhammadu pointed to a place in the veranda and there I made my ishä prayers in front of the crowd. No one made the slightest sound while they watched me. The whole crowd of women and children kept the most rigorous silence, which I found remarkable, especially from the part of the very small children. After my prayer was over, all of them looked at me with admiration in their faces.

A table was brought to the middle of the veranda and uncle Abdurrazzag made me sit down close to it. On the inner side of the veranda there was the wall of the house with tall windows. The roof was supported by solid pillars. There was a railing around the other three sides and, beyond it, dark vegetation. An incense burner was put in the middle of the table and Abdurrazzag brought a book written in Arabic. It was the Buruda, ${ }^{13}$ a book of religious poetry we Maldivians know well. I began reciting it. En-

13 Qasiida al-Burda (قصيدة البردة), written by Imam al-Busiri, a Sufi of Egypt. The book has 10 chapters with 160 rhyming verses. 
couraged by my friend I went on reading aloud for about two hours. Meanwhile everyone, including the small children, kept the most absolute silence.

After I finished reading food was brought for me and everyone watched me eating. This time the silence was broken by whispers.

It was late, but only close to midnight Muhammadu finally said: "Let's go to my home. You will sleep there." He did not tell me anything else, but he seemed to have been arguing with his uncle about where it would be better for me to spend the night.

We went out into the night and began walking towards his home. The path was narrow and we walked again for a long time in utter darkness. At last we arrived to a clearing where there was a single, long house lit by petrol lamps (fänüs). I could hear people's voices and laughter but could not see anyone.

Then I discerned an old man quietly sitting in the veranda. My friend introduced me to him: "Bappā" (father), he said in the Maldivian language. He brought me then to the first room close to the veranda, pointed to the bed and that is where I slept.

It was long past midnight and I was exhausted. So as soon as I lay on the bed I fell asleep. All of a sudden I was woken up by wild yelling, followed by beating noises. It was frightening. I could not tell what was going on and did not know what to do, so I remained very quiet. I waited for a long time and then saw my friend rushing out past the door holding a thin long snake by the tail. He was followed by the women and children and came back to show it to me saying that it was poisonous. I got up and looked at it; the snake was green and I could see with relief that it was dead.

The snake was thrown away and everyone went to bed, but I found it harder to sleep now. Somehow I dozed and then woke up at dawn. I prayed and then I sat down in the veranda. The children and the women were already awake, remaining at the back of the house, but every now and then they would sneak a look at me.

My friend's father came and joined me and we sat together in silence. Towards mid-morning an old man walked alongside the veranda. Muhammadu's father commented: "One of your people."

The father clapped his hands and shouted: "This is a Maldibi man," pointing at me. The man stopped and came towards us. He was a dark man with a towel on his shoulders. He spoke to me in Male' language and told me that his name was Kalhu Huttu. He asked me if I knew Atirige Abdullahi Didi and I said I had heard of him. Then he relaxed, sat down, and we talked for a while.

Kalhu Huttu had been living in Ceylon for thirty years. He had come there on a trip with Atirige Abdullahi Didi and had stayed since then. He was sixty now. He liked the place and had married a local woman and had children. He said: "I like to live here much more than in the Maldives. Life is less difficult." He had not been back to the islands all these years, but friends and relatives had come to visit him every now and then.

Kalhu Huttu brought me to his house. He showed me the Bodu Tartíbu, an important religious book in our culture. He had many other books too. We talked a long time about the islands and about religion. A tall and lean girl came in. Kalhu Huttu introduced me to her as his daughter and told her in Divehi: "This man is one of our people." She smiled and addressed me in our language; but I noticed that she spoke Divehi 
with difficulty. She went away and came back serving tea for us, happy that her father had visitors from his country. She was beautiful and straightforward, looking a lot like a woman from the Maldives, except for the fact that she was rather tall.

When I told Kalhu Huttu I had to leave he went along with me to Muhammadu's house. Although my friend had originally planned to travel back to Galle that evening, once we reached the place I was told that we would not leave. Muhammadu Nüru was very ill in bed. Since his condition did not improve I had to stay for two more days at his home and began to grow restless. The place was pleasant and my hosts gentle and generous, but on the third day I expressed my concern that the vedi, my ship, may leave soon. Thus, before that night my friend, still in his sickbed, made arrangements for me to leave at once. He pointed out that it was important that someone should accompany me to Veligama, so that I would be able to board a bus to Galle. Finally it was decided that Kalhu Huttu's son would go with me.

We left that same night on an oxcart taking the long narrow road across the jungle. Before dawn we arrived at Veligama. The electric lights of the town looked very bright after the darkness of the forest. Kalhu Huttu's son brought me to a shop belonging to the Nūru family. He called for a long time until the people inside finally woke up and opened the door. They told us that the bus to Galle would leave at eleven o'clock. They were sleepy and in no mood to entertain guests. I could see that all they wanted was to go back to sleep. Kalhu Huttu's son admitted he was tired too; he wanted to stay there and sleep. Thus I resolved to leave them there and went to the mosque.

I was curious to see how the mosque of the town was, but when I entered it was crowded with people sleeping on the floor. The mudimu came and when he shouted the call to prayer, most of the sleepers woke up, took their bundles and left. Hardly any people remained to pray along with me.

When I went out the dawn light was clear on the sky, but the sun had not yet risen. I was wondering what to do until eleven in that town when just across the street from the mosque I saw a large clean-looking two storey house. It looked like a home of a wealthy person. A man with a black beard was standing at the gate with his face turned towards the street. He wore a white shirt and a white skull-cap. In his hands he had a rosary and was muttering softly while moving the beads, looking at no one.

It is not easy for me to approach people I do not know in a foreign place, but this time I thought: "I will talk to him." So I gathered courage, crossed the street, walked straight to the man and introduced myself as a man from Maldibi.

His face lit up and he smiled at me. Almost immediately he asked me if I knew sorcery (fandita). We Maldivians often get asked this question while abroad, because we have a wide reputation for being sorcerers in the countries where they know us. When I told him that I did he let me know that in the house there was a woman who was very sick. Apparently she had a very strong pain in the belly and he requested me to make sorcery for her. When I said I would, he invited me to enter the house.

I was promptly ushered into the room where a woman was lying on a bed clearly suffering. I asked questions and was told that the pain was not from pregnancy, but from the stomach. Then I instructed the women of the household to toast rice until it was black. 
When they brought it I prepared ink with it, by crushing it into a fine powder and adding water. I asked for a small bamboo pen and a porcelain plate. After I wrote inside the surface of the dish, I asked them to try to find miribi leaves, for I had also seen the plant in Ceylon. ${ }^{14}$ I told them to squeeze the leaves with water and to bring me the juice.

I had time to wait, but to my amazement the liquid was brought very quickly. I recited some words over it and dissolved the words written on the porcelain plate with the green juice. Then I gave the mixture to the sick woman to drink and her pain eased almost instantly. The whole family was relieved and they stared at me in wonder. They saw it as a sign of God that I had been brought to their home. Then the adult men and women of the house surrounded me, asking me to write little strips of paper for them (Tavidu). ${ }^{15}$ I agreed but told them that they would have to pay two rupees for each paper I wrote. Paper and a pen were immediately brought and I began to cut the paper into narrow strips. Then I wrote a text in Arabic on every Tavidu, cashing two rupees for each. At the end I had collected eighty rupees.

Everyone in the household wanted me to stay on, but I respectfully told the owners that I really had to leave, because it was close to eleven o'clock and I should not miss the bus to Galle. They saw my anxiety and agreed, but clearly regretted seeing me leaving so soon.

I headed straight for the square and sat in the bus. When I arrived in Galle I first entered a hotel and had a good meal, then I went to the harbour and boarded our vedii. Once aboard the traders and sailors said that they had been looking for me. They assured me that they were all ready to leave right away and that if I would have arrived a day later they would have sailed away. Then tea was served and I told them about my adventures ashore.

Actually the ship did not leave that same evening. We had to wait another whole day and left only the following day at nightfall.

\section{BIBLIOGRAPHY}

Bābage D., Divehi Ādakāda (Maldivian customs), Divehi Bahāi Tārikhah Khidmaiykurā Qaumī Markazu, Male' 1993.

Bell H.C.P., The Máldive Islands. Monograph on the History, Archaeology and Epigraphy, s. I. 1940.

Divehi Tärikhah Au Alikameh (New light on Maldivian history), Divehi Bahāi Tārikhah Khidmaiykurā Qaumī Markazu, repr. 1958, edn. Male’ 1990.

Fitzpatrick S., Callaghan R., 'Seafaring Simulations and the Origin of Prehistoric Settlers to Madagascar' in G. Clark, F. Leach, S. O'Conor (eds.), Islands of Inquiry. Colonisation, Seafaring and the Archaeological of Maritime Landscapes, Canberra 2009 (Terra Australis, 29).

14 Mirihi is a fast-growing flowering Asteraceae shrub (Melanthera biflora) very common in the islands.

15 Long paper strips with religious writing in Arabic script that are rolled and kept close to the body by means of a string, often inside a small watertight metallic tube, in order to ward off sickness and evil. 
Gardet L., Les hommes de l'Islam. Approche des mentalités, Paris 1977 (Le Temps \& Les Hommes). Green J., 'The Archaeological Contribute to the Knowledge of the Extra-European Shipbuilding at the Time of the Medieval and Modern Iberian-Atlantic Tradition' in F.J.S. Alves (ed.), Proceedings, International Symposium on Archaeology of Medieval and Modern Ships of Iberian-Atlantic Tradition. Hull Remains, Manuscripts and Ethnographic Sources. A Comparative Approach, Lisboa 2001 (Trabalhos de Arqueologia, 18).

Ibn Battuta, Travels in Asia and Africa, trans. by H.A.R. Gibb, London 1929.

Koechlin B., 'Notes sur l'histoire et le navire long-courrier, odi, aujourd'hui disparu, des Maldives', Archipel, Vol. 18, No. 1 (1979).

'Letters to England 1727-1737' in J. Tyrell, Return to Maldivia: Happy Ending or Anti-Climax?, 12 April 2013, at <http://johntyrrell.blogspot.com/2013/04/return-to-maldivia-happy-ending-or-anti.html $>$.

Maloney C., People of the Maldive Islands, New Delhi 1980, ed. 2013.

Munch-Petersen N.F., 'The Maldives. History, Daily Life and Art-handicraft', Bulletin du CEMOCI, Vol. 1, No. 1/2 (1982).

Romero-Frias X., Folk Tales of the Maldives, Copenhagen 2012.

Romero-Frias X., The Maldive Islanders. A Study of the Popular Culture of an Ancient Ocean Kingdom, Barcelona 1999.

Shafìgu A., Oḍidonifaharu Banun (Construction of Maldivian boats), Divehi Bahāi Tārikhah Khidmaiykurā Qaumī Markazu, Male’ 1991.

Smyth H.W., Mast and Sail in Europe and Asia, London 1906.

Xavier ROMERO-FRIAS - Spanish writer and scholar, an expert in anthropology and linguistics. He has investigated the folklore and oral tradition of the Maldives, beginning in 1979, and has learnt two dialects of the Maldivian language fluently. He has also completed the English translation of hundreds of Maldivian tales and legends of the Maldives. He is fluent in nine languages. His present residence is in Bangkok. 